\title{
INVESTIGATION OF INFLUENCE OF REINFORCEMENT
}

\author{
KONOVALOVA, O[lga]
}

\begin{abstract}
This investigation contains the research of the influence $90^{\circ}$-layers on the buckling stability of the isolated cell of a composite plane wing plating; and the research how the layers arrangement order in the laminate affects to the critical pressure of the cell's buckling stability loss. Influence of the structure on the stability of the composite panel with different way supported edges at pure compression is estimated for obtaining the optimum structure.
\end{abstract}

Key words: buckling stability, laminate, layer, eigenvalue

\section{INTRODUCTION}

From large number of studies and numerical simulations, it was determined that laminate structure should include layers with layup $0^{\circ}$ and $\pm 45^{\circ}$ relative to loading direction. According to numerous tests results, it is known that structures of plane skins bearing surfaces should have a number of (10-15\%) of $90^{\circ}$-layers (James\&Starnes, 1979). Fiber orientation angle $90^{\circ}$ appears in connection with restrictions on the stability loss. The early efforts in which the existing metal structural components were simply replaced by composite ones with reasonably well understood laminates, such as the commonly used quasiisotropic layup with $0^{\circ}, \pm 45^{\circ}$, and $90^{\circ}$ oriented fibers, proved to fall short of the expectations (Gürdal, 2005).

This paper investigates the influence of $90^{\circ}$-layers on stability of isolated cells with hinged edges. In the research are considered variants of behavior of the layered plate with constraints as well as with free deformations in the transverse direction. The results show a complex interaction between plate orthotropy and boundary conditions (Baba, 2007). Laminates with clamped edges are found to be more susceptible to failure due to the transverse shear and delamination, while those with the simply supported edges undergo total collapse at a load slightly higher than the fiber failure load (Singh et al.,1997). It shows the difference between laboratory material tests results and material exploitation properties in real constructions.

Another aspect of this work is the investigation how the layers arrangement order in the laminate affects on the cell's critical buckling stress.

For the initial reliability assessment of numerical simulation as an understudy object is chosen the plate to which one could be easily obtained analytical results. Thus, the skin is presented in the form of rectangular $650 \times 130 \mathrm{~mm}$ laminated cells (with respect to stringer's and rib's steps). Materials: epoxy matrix is reinforced by carbon fiber tape. Thickness of one layer is 0,12 $\mathrm{mm}$, of the entire plate $-2,4 \mathrm{~mm}$. Mechanical properties: $\mathrm{E}_{1}=14,3 \mathrm{GPa}, \mathrm{E}_{2}=840 \mathrm{MPa}, \mathrm{G}_{12}=560 \mathrm{MPa}, \mu_{12}=0,36$.

\section{RESEARCH AND MAIN RESULTS}

The results of stability research of skin cells are obtained numerically by the finite-elements modeling and calculated by computer complex NASTRAN MSC Software. Panels are simulated with different structures.

Each structure is considered for two cases: with constraints and free transverse strains.
The compressive load is distributed per length and calculated according to value of the critical stress.

The calculations of plates for buckling stability are performed and the lowest buckling modes and corresponding eigenvalues for different variants of structures and boundary conditions are determined and shown in table 1.

\begin{tabular}{|c|c|c|c|c|c|c|c|}
\hline \multicolumn{2}{|c|}{$\begin{array}{l}\text { Structure } \\
\text { relatively to NS* }\end{array}$} & $\begin{array}{c}-\mathrm{NS} \\
0_{6} \\
45_{4} \\
90_{0} \\
\end{array}$ & $\begin{array}{c}-\mathrm{NS} \\
0_{6} \\
45_{3} \\
90_{1} \\
\end{array}$ & $\begin{array}{c}-\mathrm{NS} \\
0_{6} \\
45_{2} \\
90_{2} \\
\end{array}$ & $\begin{array}{c}-\mathrm{NS} \\
0_{5} \\
45_{5} \\
90_{0} \\
\end{array}$ & $\begin{array}{c}-\mathrm{NS} \\
0_{5} \\
45_{4} \\
90_{1} \\
\end{array}$ & $\begin{array}{c}\text { - NS } \\
0_{5} \\
45_{3} \\
90_{2} \\
\end{array}$ \\
\hline & & \multicolumn{3}{|c|}{$0_{60 \%} * *$} & \multicolumn{3}{|c|}{$0_{50 \%} * *$} \\
\hline \multicolumn{2}{|c|}{ Variant } & 1 & 2 & 3 & 4 & 5 & 6 \\
\hline \multirow{3}{*}{$\begin{array}{l}\text { Free } \\
\text { edges }\end{array}$} & $\begin{array}{l}\sigma_{\mathrm{rr}}^{* * * \cdots * * *} \\
\mathrm{~kg} / \mathrm{mm}^{2}\end{array}$ & 7,72 & 6,86 & 5,97 & 8,12 & 7,18 & 6,15 \\
\hline & $N_{x} * * * *$ & 4 & 5 & 6 & 5 & 5 & 6 \\
\hline & $\underset{\mathrm{kg} / \mathrm{mm}}{\boldsymbol{q}_{\boldsymbol{x}},}$ & 18,52 & 16,46 & 14,33 & 19,48 & 17,22 & 14,76 \\
\hline \multirow{3}{*}{$\begin{array}{l}\text { Hinged } \\
\text { supported } \\
\text { edges }\end{array}$} & $\begin{array}{l}\sigma_{\mathrm{cr}}^{* * * * * * *} \\
\mathrm{~kg} / \mathrm{mm}^{2}\end{array}$ & 6,00 & 6,11 & 5,57 & 5,73 & 6,13 & 5,60 \\
\hline & $N_{x^{* * * * *}}$ & 3 & 5 & 5 & 2 & 4 & 6 \\
\hline & $\underset{\mathrm{kg} / \mathrm{mm}}{\boldsymbol{q}_{\boldsymbol{x}},}$ & 14,41 & 14,67 & 13,38 & 13,75 & 14,72 & 13,44 \\
\hline
\end{tabular}

\begin{tabular}{|c|c|c|c|c|c|c|c|}
\hline \multicolumn{2}{|c|}{$\begin{array}{l}\text { Structure } \\
\text { relatively to NS* }\end{array}$} & $\begin{array}{c}\text { - NS } \\
0_{4} \\
45_{6} \\
90_{0} \\
\end{array}$ & $\begin{array}{c}\text { - NS } \\
0_{4} \\
45_{5} \\
90_{1} \\
\end{array}$ & $\begin{array}{c}-\mathrm{NS} \\
0_{4} \\
45_{4} \\
90_{2} \\
\end{array}$ & $\begin{array}{c}-\mathrm{NS} \\
0_{3} \\
45_{7} \\
90_{0} \\
\end{array}$ & $\begin{array}{c}-\mathrm{NS} \\
0_{3} \\
45_{6} \\
90_{1} \\
\end{array}$ & $\begin{array}{c}\text { - NS } \\
0_{3} \\
45_{5} \\
90_{2} \\
\end{array}$ \\
\hline & & \multicolumn{3}{|c|}{$0_{40 \%} * *$} & \multicolumn{3}{|c|}{$0_{30 \%} * *$} \\
\hline \multicolumn{2}{|c|}{ Variant } & 7 & 8 & 9 & 10 & 11 & 12 \\
\hline \multirow{3}{*}{$\begin{array}{l}\text { Free } \\
\text { edges }\end{array}$} & 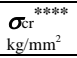 & 8,33 & 7,30 & 6,27 & 8,46 & 7,38 & 6,30 \\
\hline & $N_{x} * * * *$ & 5 & 6 & 6 & 5 & 6 & 7 \\
\hline & $\underset{\mathrm{kg} / \mathrm{mm}}{\boldsymbol{q}_{\boldsymbol{x}}}$ & 19,99 & 17,53 & 15,04 & 20,30 & 17,70 & 15,12 \\
\hline \multirow{3}{*}{$\begin{array}{c}\text { Hinged } \\
\text { supported } \\
\text { edges }\end{array}$} & $\begin{array}{l}\sigma_{\mathrm{cr}}^{*} * * * ; \\
\mathrm{kg} / \mathrm{mm}^{2}\end{array}$ & 4,85 & 5,94 & 5,50 & 3,99 & 5,60 & 5,30 \\
\hline & $N_{x}$ ***** & 1 & 4 & 6 & 1 & 4 & 5 \\
\hline & $\underset{\mathrm{kg} / \mathrm{mm}}{\boldsymbol{q}_{\boldsymbol{x}},}$ & 11,64 & 14,26 & 13,21 & 9,57 & 13,43 & 12,73 \\
\hline
\end{tabular}

\begin{tabular}{|c|c|c|c|c|c|c|c|}
\hline \multicolumn{2}{|c|}{$\begin{array}{l}\text { Structure } \\
\text { relatively to NS* }\end{array}$} & $\begin{array}{c}-\mathrm{NS} \\
\mathrm{O}_{2} \\
45_{8} \\
90_{0}\end{array}$ & $\begin{array}{c}\text { - NS } \\
0_{2} \\
45_{7} \\
90_{1}\end{array}$ & $\begin{array}{c}-\mathrm{NS} \\
0_{2} \\
45_{6} \\
90_{2}\end{array}$ & $\begin{array}{c}-\mathrm{NS} \\
0_{1} \\
45_{9} \\
90_{0}\end{array}$ & $\begin{array}{c}\text { - NS } \\
0_{1} \\
45_{8} \\
90_{1}\end{array}$ & $\begin{array}{c}\text { - NS } \\
0_{1} \\
45_{7} \\
90_{2}\end{array}$ \\
\hline & & \multicolumn{3}{|c|}{$0_{20 \%}$ ** } & \multicolumn{3}{|c|}{$0_{10 \%}{ }^{* *}$} \\
\hline \multicolumn{2}{|c|}{ Variant } & 13 & 14 & 15 & 16 & 17 & 18 \\
\hline \multirow{3}{*}{$\begin{array}{l}\text { Free } \\
\text { edges }\end{array}$} & $\begin{array}{l}\sigma_{\mathrm{rr}}^{* * * * * * * * * *} \\
\mathrm{~kg} / \mathrm{mm}^{2}\end{array}$ & 8,53 & 7,41 & 6,30 & 8,55 & 7,43 & 6,31 \\
\hline & 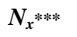 & 5 & 6 & 7 & 5 & 6 & 7 \\
\hline & $\underset{\mathrm{kg} / \mathrm{mm}}{\boldsymbol{q}_{\boldsymbol{x}},}$ & 20,46 & 17,79 & 15,13 & 20,52 & 17,82 & 15,14 \\
\hline \multirow{3}{*}{$\begin{array}{l}\text { Hinged } \\
\text { supported } \\
\text { edges }\end{array}$} & $\begin{array}{l}\sigma_{\mathrm{cr}}^{* * * * * * * *} \\
\mathrm{~kg} / \mathrm{mm}^{2}\end{array}$ & 3,21 & 4,91 & 4,96 & 2,51 & 3,79 & 4,45 \\
\hline & 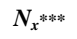 & 1 & 2 & 5 & 1 & 1 & 4 \\
\hline & $\underset{\mathrm{kg} / \mathrm{mm}}{\boldsymbol{q}_{\boldsymbol{m}},}$ & 7,69 & 11,78 & 11,91 & 6,03 & 9,10 & 10,68 \\
\hline
\end{tabular}

*Symmetrical layup with respect to the laminate neutral surface (NS). *** In the notation $0 \mathrm{n} \% \mathrm{n}$ - percentage of $0^{\circ}$-layers in the package.

$* * * \boldsymbol{N}_{\boldsymbol{x}}$-number of half-waves.

$* * * *$ Loading - pure compression along the " $\mathrm{X}$ "axis. $\sigma_{\mathrm{cr}}$ is a critical stress for cell.

Tab. 1 Influence of Material Structure on the Isolated Cell Buckling Stability 
From the structures is chosen the most stable one (with the highest critical stress) in the case of limited transverse strains as the most typical. The influence of the various layers location (with respect to the neutral axis) on the cell's general stability is determined by varying layers order. The critical buckling stress values for hinged supported bearing structures with $10 \%$ of $90^{\circ}$-layers for structures with different order of the layup are obtained and shown in table 2 .

\begin{tabular}{|c|c|c|c|c|c|c|c|}
\hline \multicolumn{2}{|c|}{$\begin{array}{c}\text { Structure } \\
\text { relatively to NS }\end{array}$} & $\begin{array}{c}-\mathrm{NS} \\
0_{5} \\
45_{4} \\
90_{1}\end{array}$ & $\begin{array}{c}-\mathrm{NS} \\
0_{5} \\
90_{1} \\
45_{4}\end{array}$ & $\begin{array}{c}-\mathrm{NS} \\
45_{4} \\
0_{5} \\
90_{1}\end{array}$ & $\begin{array}{c}-\mathrm{NS} \\
45_{4} \\
90_{1} \\
0_{5}\end{array}$ & $\begin{array}{c}-\mathrm{NS} \\
90_{1} \\
0_{5} \\
45_{4}\end{array}$ & $\begin{array}{c}-\mathrm{NS} \\
90_{1} \\
45_{4} \\
0_{5}\end{array}$ \\
\hline & & \multicolumn{6}{|c|}{$0_{50 \%}$} \\
\hline \multicolumn{2}{|c|}{ Variant } & 5.0 & 5.1 & 5.2 & 5.3 & 5.4 & 5.5 \\
\hline \multirow{3}{*}{$\begin{array}{l}\text { Hinged } \\
\text { supported } \\
\text { edges }\end{array}$} & $\underset{\mathrm{kg} / \mathrm{mm}^{2}}{\sigma_{\mathrm{c}}}$ & 6,13 & 6,32 & 3,98 & 2,45 & 5,7 & 2,06 \\
\hline & $N_{x_{i}}$ & 4 & 3 & 4 & 2 & 2 & 1 \\
\hline & $\underset{\mathrm{kg} / \mathrm{mm}}{q_{0}}$ & 14,72 & 15,17 & 9,54 & 5,89 & 13,68 & 4,95 \\
\hline
\end{tabular}

Tab. 2 Influence of material structure on the buckling stability of the isolated cells at $10 \%$ content of the $90^{\circ}$-layers

Fig.1 shows the critical buckling stresses of the cell with $10 \%$ of $90^{\circ}$-layers with different support conditions (variant 5 in Table 1). Fig. 2 shows the critical buckling stresses of the most stable panel with $10 \%$ of $90^{\circ}$-layers and hinged supported edges (variant 5.1 in Tab.2).

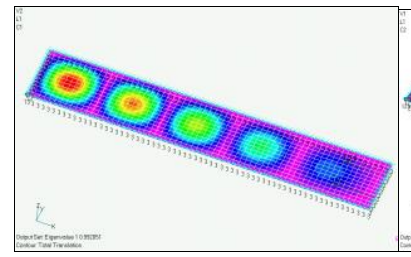

a)

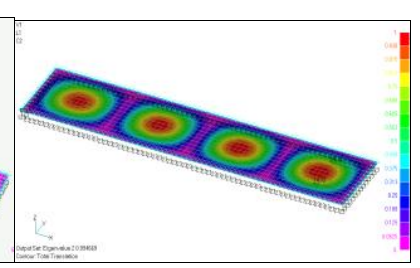

b)
Fig. 1. Critical buckling stress of cell with $10 \%$ of $90^{\circ}$-layers with a)free edges; b) hinged supported edges (Tab.1, variant 5).

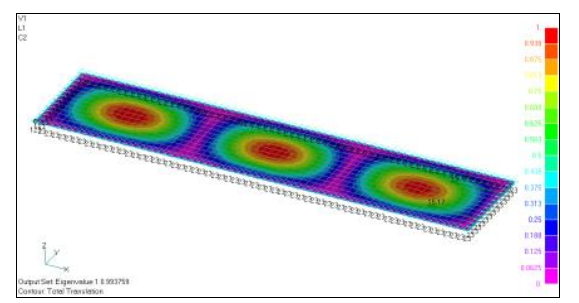

Fig.2. Critical buckling stress of the most stable cell with $10 \%$ of $90^{\circ}$-layers and hinged supported edges (Tab.2, variant 5.1).

Fig. 3-5 show the critical buckling stresses of the cell with different percentages of $90^{\circ}$-layers under different support conditions.

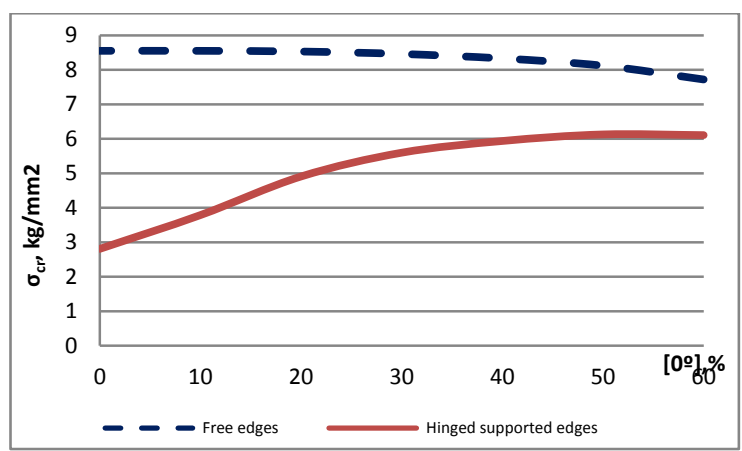

Fig. 3. Diagram of cell's critical buckling stresses at $0 \%$ content of $90^{\circ}$ - layers

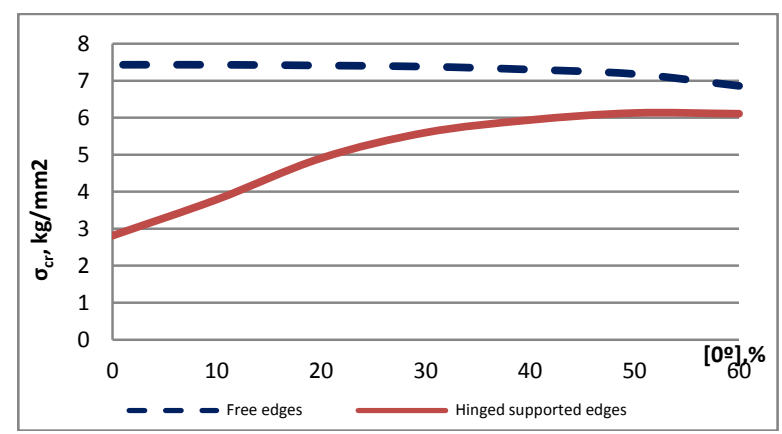

Fig. 4. Diagram of cell's critical buckling stresses at $10 \%$ content of $90^{\circ}$-layers

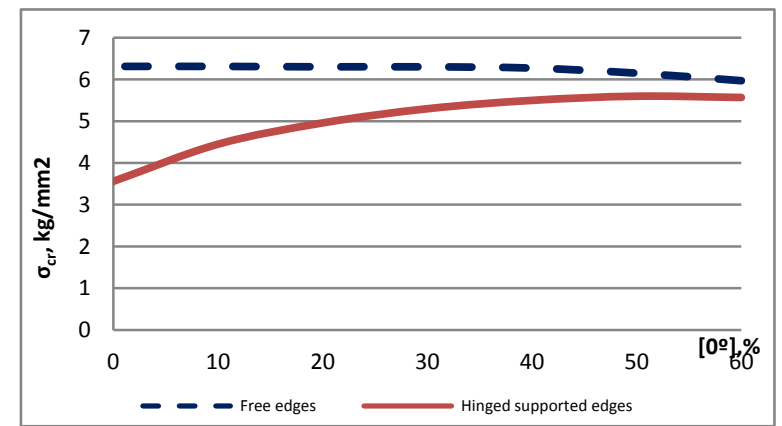

Fig. 5. Diagram of cell's critical buckling stresses at $20 \%$ content of $90^{\circ}$-layers

\section{CONCLUSION}

For laminate composite skin panels with characteristic for the bearing surface dimensions $10 \%$ of $90^{\circ}$-layers in the structures with layup of $0^{\circ}$ and $\pm 45^{\circ}$ significantly improves the results of buckling stability of the cell (variant 5 in Tab.1). As the results of study of the alternating layers effect, the most closest to optimal are structures in which layers of $\pm 45^{\circ}$ are located at the edges (outside) the laminate (variant 5.1, in Tab.2).

\section{ACKNOWLEDGEMENTS}

The author is grateful to Gorobets P.and Vasilevsky E., Kiev, Ukraine, for their support in carrying out this work.

\section{REFERENCES}

Baba, B.O.(2007), Buckling behavior of laminated composite plates, Journal of Reinforced Plastics and Composites, Vol. 26, No. 16, November 2007, pp.1637-1655, ISSN: 07316844

Gürdal, Z.(2005), Design Tailoring of Laminated Composite Structures A Tribute to Dr. James H. Starnes, Jr., Available from:

http://www.abdmatrix.com/phcdl/upload/design/Design\%2 0Tailoring\%20of\%20laminated $\% 20$ Composite $\% 20$ Structur es.pdf, Accessed: 2005-04-18

Gürdal, Z., Haftka, R.T.(1993), Optimization of Composite Laminates, In: Optimization of Large Structural Systems, NATO ASI Series, Ed. Rozvany G.I.N., Vol. 2, pp. 623-648, Kluwer Academic Publishers, ISBN:0-7923-2129-4, Dordrecht, Netherlands

James, H., Starnes, Jr.(1979), Preliminary Design of Composite Wings for Buckling, Strength and Displacement Constraints, Journal of Aircraft, Vol. 16, pp.564-570.

Singh S.B, Kumar A. \& Iyengar N.G.R.(1997), Progressive Failure of Symmetrically Laminated Plates under Uni-axial Compression, Structural Engineering and Mechanics, Vol. 5, No. 4, July 1997, Pages 433-450. ISSN: 12254568 